\title{
CPEC and Food Security: Empirical Evidence From Pakistan
}

\author{
Nida Baig (Corresponding Author) \\ College of Public Administration, Huazhong University of Science and Technology, \\ Wuhan, China \\ E-mail: nida_iiie@yahoo.com \\ Dr. Chen He, Professor \\ College of Public Administration, Huazhong University of Science and Technology \\ Wuhan, China \\ E-mail: ch1797@sina.com
}

\begin{abstract}
Dr. Shahbaz Khan, Assistant Professor
Department of Management Sciences, Foundation University Islamabad, Rawalpindi Campus

E-mail: shahbaz.khans@yahoo.com
\end{abstract}

Salman Ali Shah

School of Economics, Zhongnan University of Economics and Law, Wuhan, china

E-mail: salmanali.eco@gmail.com

Received: Feb. 3, 2019 Accepted: Mar. 4, 2018 Online published: Mar. 12, 2019 doi:10.5296/jpag.v9i1.14309 URL: https://doi.org/10.5296/jpag.v9i1.14309

\section{Abstract}

Among the various major issues, food insecurity is one with which Pakistan has to encounter 
with. According to a report by WFP (2017), about sixty percent of the population in Pakistan is food insecure, access to food is limited or uneven, and malnutrition is widespread. Having an emerging geopolitical prestige, it is expected that through CPEC, Pakistan can get a better foundation of infrastructural -and agricultural economic zones in collaboration with Chinese counterparts which may further support to perk up the food security. Accordingly, the study tries to examine the impact of various CPEC initiatives on food security of Pakistan. The data is randomly collected from stakeholders working in various government sector organizations of Pakistan. The results show that CPEC initiatives would tend to improve the food security status in Pakistan. The research may suggest that developing countries like Pakistan may use economic corridors such as CPEC as a strategic tool to improve the food security situation.

Keywords: Foreign Direct Investment, China-Pakistan economic Corridor, Pakistan, China, Food Security

\section{Introduction}

In this socioeconomic era, it is indispensable to ignore the importance of food security. It has become a global agenda to optimize the food security measures as it may cause hunger and malnutrition in the population groups which may further direct a nation towards famine and conflict (Mohsen, 2017). To cope up with food insecurity in developing countries, especially, where poverty level is too high, seems to be the considerable challenge for the economists and practitioners because of its strong correlation with the social stability. According to a recent report by FAO (2017), over the past three years, the people who are facing chronic food deficiency have been increased from 804 million undernourished people to 821 million people, and majority of them are from developing countries.

Several developmental organizations suggest bringing foreign direct investment (FDI) in these developing countries because of its potential to control the inequalities (Choi, 2006), and ability to narrow the financial gaps which may further reduce the national poverty level, so ultimately may assist to control the food insecurity (Voss, 2016). The economic corridor is one of the main drivers of FDI, so could boost up economic activities along with developing high standards of transport infrastructure, and agricultural productivity, and ultimately by attributing a significant growth to food regions (Dobermann et al., 2013).

In 2014, Chinese President Mr. Xi Jinping launched OBOR plans to connect China with more than 60 countries. Indubitably, "OBOR” (One Belt One Road), with the alternative title: BRI (Belt and Road Initiative), and the full title: The Silk Road Economic Belt and the 21st-century Maritime Silk Road, is a most aspiring and mega project of the early 21stcentury (Chohan, 2017). It can be considered as a new passage where the regional and economic negotiation can be carried out between the Asia, Europe and Africa (Irshad, 2015). China-Pakistan Economic Corridor (hereinafter referred to as CPEC) is a part of OBOR' initiative and, is the China's giant foreign direct investment in Pakistan till now. CPEC is a best example of Pakistan-China strategic partnership which has been designed to sprout the relationship between these two countries as well as to achieve the economic goals.

The CPEC plans stayed to be impervious during its initial years of functioning but, recently 
in July 2017, some of its additional plans changed its image as a heavy energy and infrastructure developmental region (National Food Security Policy, 2017). In fact, along with its development in energy and transport sectors, it would have a plan to take thousands acres of agricultural land on lease and, Chinese enterprises are scheduling to construct their demonstration projects in this land which involves improvement in seed varieties as well as introduction of latest irrigation technologies and, going to encourage policy environment for potential investors. Thereby, contrary to the common man's image about CPEC plans, the food security of Pakistan is going to be the main thrust of its strategic goals (Hussain, 2017).

Within this context, this research focuses on assessing the impact of CPEC initiative on food security of Pakistan. It is important as WFP (2017) reported that approximately 60 percent of population in Pakistan is subjected to food insecurity risk. So, the research may direct government of Pakistan to implement CPEC encouragement policies which in turn may help Pakistan to come out of this alarming socio-economic issue (Food Security).

The study is composed of following sections: Section 2 will present a conceptual framework of the study; section 3 will put a comprehensive light on food security condition in Pakistan; section 4 will present a comprehensive literature review in order to develop the hypotheses; section 5 will present research methodology; section 6 will report the findings, and finally section 7 will conclude the overall paper.

\subsection{Conceptual Framework}

This paper focuses on assessing the perceptions of various stakeholders directly or indirectly involved in CPEC about the impact of three main CPEC initiatives i.e., Economic Initiatives, Agricultural growth initiatives, and infrastructural development initiatives on food security of Pakistan. So, economic initiatives, agriculture initiatives, and infrastructure initiatives are taken as independent variables, and food security as dependent variable in this study as shown in figure 1. We also take stakeholder's involvement as moderating variable. The idea is that if a concerned stakeholder has a deep engagement, interest, and involvement in CPEC region than others, he would tend to strengthen the relationship between a CPEC initiatives and food security. The reasons might include his better knowledge, deep understanding, and direct involvement in CPEC. 


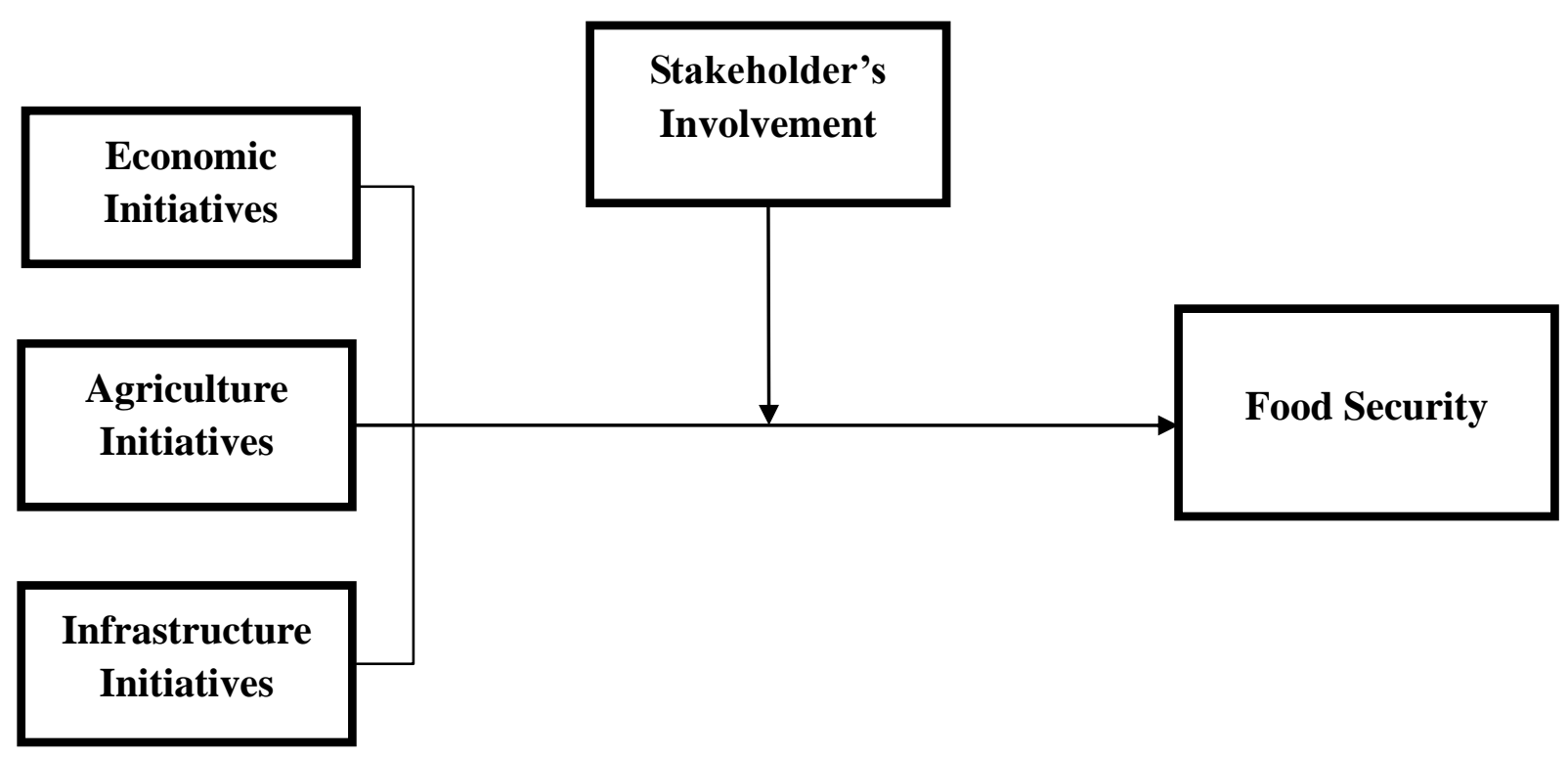

Figure 1. Conceptual Framework (CPEC Initiatives and Food Security: Moderating Role of Stakeholder's Involvement)

\subsection{Food Security Condition in Pakistan}

The history of Pakistan shows its long scuffle against the shortage of food and inefficiencies in agriculture sector (Chaudhri, 2017). Pakistan is considered as agriculture economy and has resources to produce adequate food for its population, but at the same time lacks of developed infrastructure that creates hurdles to manage and distribute the food efficiently. The possible reasons might include: inadequate research and development programs to generate good variety of seeds; poor planning; compromised supply chain; incapable marketing; and lack of proper government intervention in agriculture sector. The poor performance in agricultural sector has raised the severity of food insecurity risk and this might be hazardous for health and economic conditions for a number of coming years (Mohsen, 2017).

Global Hunger Index (2017) ranked Pakistan 106th out of 119 qualifying countries. With a score of 32.6, its status is 'serious' (bordering on 'alarming') (Grebmer et al., 2017), indicating food insecurity is one of the major problems that the Pakistan was, is, and would be facing. According to a report by WFP (2017), about sixty percent of the population of Pakistan is food insecure, access to food is limited or uneven and malnutrition is far-flung. 


\section{GHI Score Trend for Pakistan}

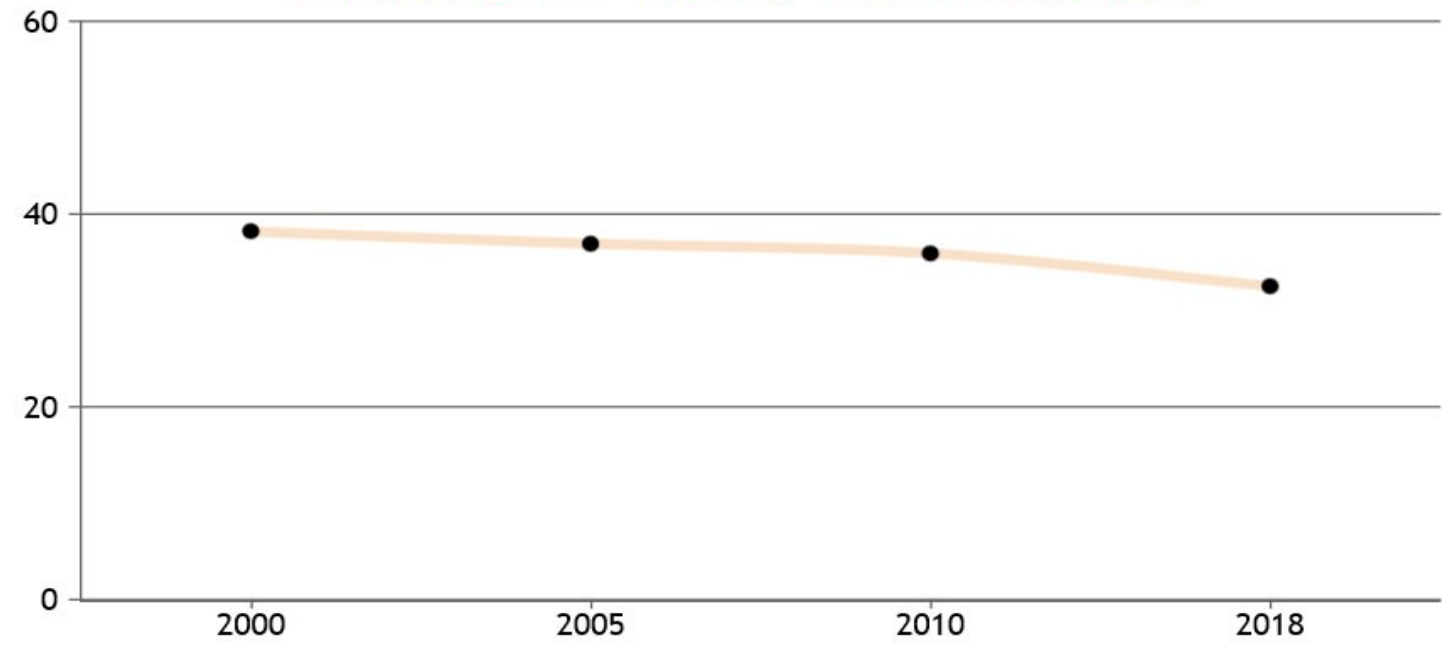

Figure 2. Food Security Status in Pakistan Since 2000 (Indicator: Hunger). Source: Global Hunger Index

\begin{tabular}{c|cccc}
\multicolumn{5}{c}{ GHI Severity Scale } \\
\hline$\leq 9.9$ & $\begin{array}{c}\text { 10.0-19.9 } \\
\text { moderate }\end{array}$ & $\begin{array}{c}20.0-34.9 \\
\text { serious }\end{array}$ & $35.0-49.9$ & $\geq 50.0$ \\
low & alarming & extremely alarming \\
\hline
\end{tabular}

Figure 3. Hunger Severity Scale. Source: Global Hunger Index (2018)

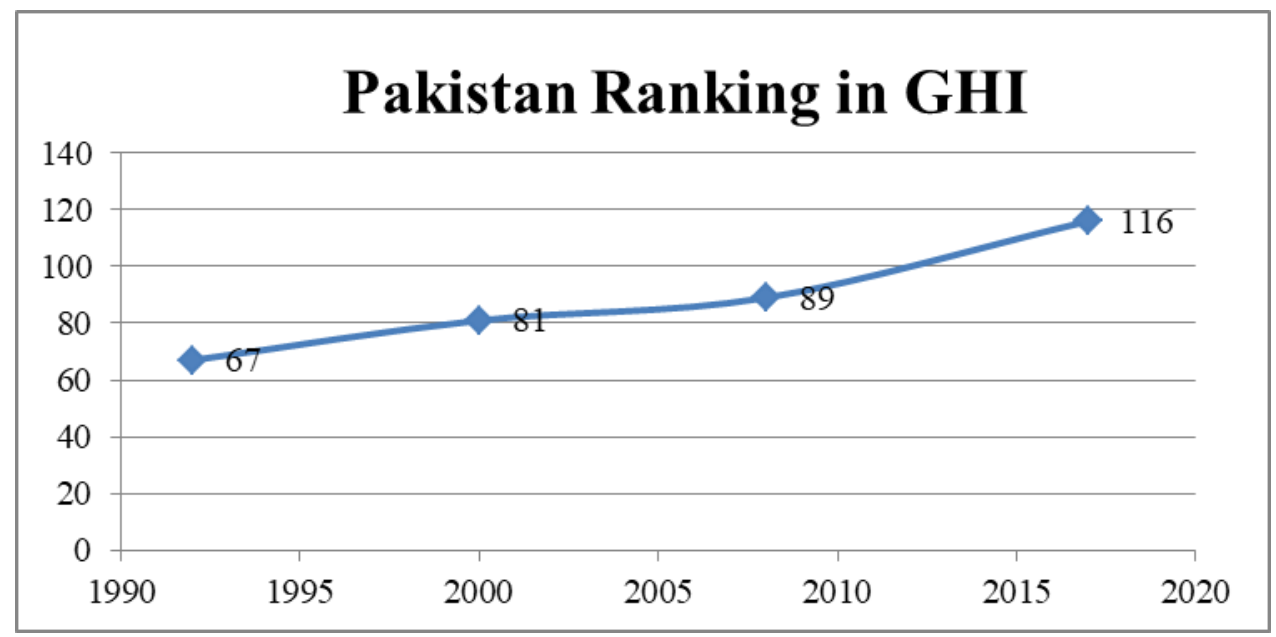

Figure 4. Pakistan's Ranking in Global Hunger Index. Data Source: Global Hunger Index

\section{Literature Review and Hypotheses Development}

Generally, the efforts and policies of a country for their development and performance play an important role to improve its food security situation (Qureshi et al., 2015), and economic partnership agreements might put a positive influence on it through different channels (Matthews, 2010). The transitional phase from hunger to food security requires the 
technological and institutional innovations (Fogel, 1991), infrastructural development, and research and development in the agriculture sector (Qureshi et al., 2015) which may be called as the heart of latest and modern economic growth (Kuznets, 1966; Mahbubul Haq, 1995; Alkire, 2002).

Sazanami (1995) and Breisinger et al. (2012) showed that economic growth plays a significant role in enhancing the food security of a country. Similarly, Jenkins and Scanlan (2001) found that economic growth with other factors like democratization and domestic investment can improve food security, and can help in reducing the hunger. In contrary, Gandhi and Zhou (2014) showed that with huge population, over a couple of decades, China and India experienced remarkable economic growth rates about $7 \%$ to $12 \%$ which ultimately change their food demand, buying and consumption behavior, and made food security as a big challenge for these two countries.

Mellor et al., (1991) discussed the economical role of agriculture in Asian countries and found that a country generates $1.5 \%$ increase in per capita non-agricultural growth via $1 \%$ increase in per capita agricultural growth. Firstly, agriculture has strong linkage to fertilizers, machinery, chemicals, food and fiber processing. Secondly, it helps in alleviation of poverty as income from agriculture sector usually spent on local goods and services, which have high income elasticity of demand and create employment (Faruqee, 1999). Accordingly, most of the studies investigating the relationship between FDI and agriculture suggested positive impact of FDI on agriculture sector depending upon the investment policies of agriculture and food production. Hallam (2011), for example, argued that FDI in agriculture might be beneficial for the host country if investor's needs are consistent to investment requirements of the host country. Timmer (2010) documented that FDI in agriculture is a solution to food crises in the long run. He argued that improving agricultural productivity led a country towards growth in food production, increase in farm income, and reduction in food prices into local markets which further ease the access of poor to food. Gerlach and Liu (2010) discussed some case studies which have shown positive impact of FDI on agricultural production of developing countries. According to Djokoto (2012), FDI inflows bring improvement in agriculture and farmer's status as they are linked with the transformation of technology and knowledge. The IFAD, FAO and WFP (2012) documented a positive link between FDI in agriculture and agricultural growth which further helps to reduce hunger and poverty. A report of UNCTAD (2017) also explained a critical role of science, technology and innovation in improving the plant varieties and agriculture inputs to produce more food. Moreover, roads, storage facilities, electricity, agro-processing facilities, know-how, communication, sanitation and other kinds of infrastructure help to make innovations that improve the quantity and quality of agricultural production.

Here, we feel necessary to put some light on the African agricultural growth corridors. These corridors have worked well to boost up African's green growth, access to food, improving fertilizers and seeds, and agricultural machinery. The agricultural development in Africa occurred mainly due to infrastructural development (Weng et al., 2013). The main concept of African agricultural growth corridors is to bring industrial agriculture by conversion of million hectors of land into infrastructure such as roads, irrigation, railways, ports, processing 
and storage (Paul and Steinbrecher, 2013).

In the context of Pakistan, its economy is passing through structural transformation. A very important and main approach is territorial or spatial development which can be attained by constructing economic corridors to boost the country's economic activities. It can stipulate a programmatic and abstracted framework for constructing socio-economic and physical effects. Specific food areas with high productivity can be developed by agro-based spatial development initiatives. Chen (2015) has declared that Pakistan would be the future leading economic power in Asia as CPEC will help it to get back its economic growth of early 1960's. CPEC will act as a game changer for Pakistan because it will boost its economy by generating three to four times more profit from investment. It will improve the life standards of almost 3 billion people of a region and will help to alleviate the poverty by providing job opportunities, infrastructure, and energy requirements and hence will get economic development. The China-Pakistan Economic Corridor initiative is trying to extend the existing transportation infrastructure of Pakistan to facilitate the transit trade and to enhance the possibilities of market accessibility ("Transportation Infrastructure," 2017). Under the project of China-Pakistan Economic Corridor approximately $\$ 11$ billion has been decided to put in motorway infrastructure. A motorway of 1100 kilometer long will be constructed from metropolitan city Karachi to Lahore, and the Karakoram highway between China and Rawalpindi will be reconstructed to make it more facilitated way ("Karachi to Lahore," 2014). The main railway track from Karachi to Peshawar will be also upgraded by December 2019 to cover large distances in minimum time. Apart from up gradation of local railway line, the railway track will be extended to connect Pakistan to China's Southern Xinjiang Railway in Kashgar ("Railway Track,"2015). A report of Deloitte (2015) has revealed the practical benefits of a route from Kashgar to Rawalpindi. The said route will provide an opportunity to traders to get maximum profit by sent their fruits to china via Xinjiang with less cost of transportation instead of using costly air cargo via Dubai. To alleviate the chronic energy shortage of Pakistan, over $\$ 33$ billion has been decided to put in construction of energy infrastructure under CPEC project (Rashid, 2015) which regularly amount to over 4,500MW ("Electricity Shortfall," 2015), and have cast an estimated 2\% to 2.5\% off annual GDP of Pakistan (Kugelman, 2015). The development of infrastructure like roads, railway tracks and energy are vital to achieve the goals of agricultural production and food security.

Under CPEC plan for agriculture, ten main areas have been identified with seventeen projects. Out of which, the protrusive point will be the construction of one NPK fertilizer plant with an annual output of 800,000 tons. Another plant in Sukkur to produce meat and milk hoping to yield an output of 200,000 tons of meat per year and 200,000 tons of milk annually. In Punjab province, the demonstration projects will be set up on more than 6500 acres for best quality and high yield seeds and irrigation. For storage and transportation of grains, fruits and vegetables, the plan intends to design a nationwide logistics network and increase the scope of warehousing and distribution network between the main cities of Pakistan. The first phase of the plan included construction of storage bases in Islamabad and Gwadar, and then Lahore, Karachi and another in Gwadar in the second phase. A vegetable processing plant with annual output of 20,000 tons, a jam and fruit juice plant with a production of 10,000 tons, and a grain 
processing plant of one million tons, will be built in Asadabad, Lahore, Islamabad and Gwadar under CPEC plans. In every field of agriculture area, the Chinese enterprises will play a major role in the production of agricultural inputs through establishment of new factories to produce pesticides, fertilizers, feed stuffs and vaccines. To build a three level warehousing system (purchase \& storage warehouse, transit warehouse and port warehouse), the Chinese investors will cooperate with local Pakistani enterprises through shareholding and joint ventures.

Furthermore, this project will directly focus on to produce quality seeds. The provincial Agriculture Extension Department is using the old inherited facilities of food production. The CPEC' project proposed to provide basic facilities to these production units such as land development, harvest facilities, lining of water course, mechanized tools for farming and post-harvest technologies to ensure the production of certified seeds. Besides the production of quality seeds, the project also proposed to strengthen the chain of seed multiplication with the help of public and private sectors, introduction of new varieties, modernizing infrastructure for seed production, certification pertaining act to ensure of quality seeds particularly compliance with the provisions of the seeds act, storage, encourage partnerships, seed standards, make sure the availability of certified seeds in conditional situations, services to dissemination and education of seed related information and communication ("Governance," 2017).

The main emphasis of the plan will be on agriculture which hopes to improve the food security issues of Pakistan. Firms who want to enter in agriculture will be entertained with extraordinary assistance from the Chinese government and China Development Bank through making of free capital and loan. The Chinese government will actively seek to employ the public special funds as the discount interest for the loans of agricultural foreign investment. The plan will also facilitate the Chinese agricultural enterprises to communicate with the representatives of Chinese and Pakistan government easily ("CPEC Investment," 2017). Details from original documents laying out the CPEC long term plan are publicly disclosed for the first time in February 2017. The outline of CPEC plan for the agriculture is very broad and will intend to improve supply chain. Chinese enterprises will not only supply basic inputs like seeds, fertilizers, pesticides and credit, but also will operate their own farms, facilitate the processing of grains, vegetables and fruits. Logistics companies will arrange transportation and storage system for agricultural production, on a large scale. It has been noted that the damage of $50 \%$ of agrarian produce during harvesting and transportation mainly due to lack of cold storage facilities could be escaped through entry of Chinese enterprises in the dysfunction agriculture sector of Pakistan. The CPEC plan will also support the activities of Xinjiang Production and Construction Corps to carry mechanization and latest scientific technique in breeding of livestock, exactitude irrigation and improvement of hybrid varieties in Pakistan.

Overall, the CPEC plans of agrarian development can help Pakistan to achieve following objectives: 1) self-efficiency in food; 2) benefits for farmers and rural residents; 3) efficient food production; 4) biodiversity; 5) feasible soil health and clean water; 6) ecological pest control management; 7) resilient food system (Hussain, 2017). Also, the previous literature 
evidenced that the role of territorial investment initiatives are vital in achieving economic growth in developing countries like Pakistan where the food insecurity is rampant, and initiatives like CPEC definitely will become a powerful source in improving food security. Hence, it seems viable to suggest the following four (3) hypotheses:

H1: Economic initiatives carried out through CPEC in Pakistan would tend to enhance the food security situation in Pakistan

H2: Infrastructural development initiatives carried out through CPEC in Pakistan would tend to spur the food security situation in Pakistan

H3: Agricultural initiatives carried out through CPEC in Pakistan would tend to improve the food security situation in Pakistan

We also take stakeholder's involvement as moderating variable. The idea is that if a concerned stakeholder has a deep engagement, interest, and involvement in CPEC region than others, he would tend to strengthen the relationship between a CPEC initiatives and food security. The reasons might be his better knowledge, deep understanding, and direct involvement in CPEC. So, fourth hypothesis of this study is as follows:

H4: Stakeholder involvement moderates the relationship between different CPEC initiatives and food security situation in Pakistan.

\section{Research Methodology}

\subsection{Data Collection}

We use survey methodology to collect the data. In this study, a total of 325 questionnaires were circulated among officials working in different government sector organizations and to the initial stakeholders, of which 143 responses were returned. Data from the officials are highly confidential and difficult to collect because representative stakeholders were from government top management. The stakeholders are taken from the following group of organizations: First of all, the key informants who involved in semi-structured interviews will come from government agencies responsible for policy formulation for China's FDI and food security. The second group consists of Academia and researchers from institutions who are related to food and agriculture. Third group involves the enterprises; companies in the field of food engineering, storage, energy, planning, climate and waste management. The final group comprises the participants who are from the media and NGOs. We take top management personnel as our stakeholders of interest because of their direct/indirect involvement in policy making. The perceptions of such stakeholders may be considered as very close towards the implementation of CPEC plans in real sense. Questionnaire consists of five-level likert scale items ranging from strongly disagree $=1$ to strongly agree $=5$.

\subsection{Pilot-Study}

A pilot study was conducted to check the reliability and validity of the adapted questionnaire. The aim was to check whether the respondents are able to understand the language, style, and structure of questions. We randomly conducted face-to- face interviews with three of our 


\section{Macrothink}

Journal of Public Administration and Governance

ISSN 2161-7104 2019, Vol. 9, No. 1

targeted respondents and observed that they are capable enough to understand the simplicity and clarity of the scale being used in the questionnaire. In addition, we check the statistical reliability with Cronbach's alpha values. We found that Cronbach's alpha values for all the variables are above the threshold limit of 0.7 (Hair et al., 2010).

\subsection{Measurement of Variables}

This study seeks to explore the relationship between different CPEC initiatives carried out in Pakistan and food security. So, food security is the dependent variable in our study. We follow previous studies by Asghar and Muhammad (2013) and Pakistan Social and living measurement survey (PSLM) to measure food security. We take economic initiatives, infrastructure initiatives, and agricultural initiatives as our main variables of interest. The components of economic -and infrastructure initiatives have been taken from the study of Ali et al., (2018), and the scale to measure agriculture initiatives have been adopted from Mozumdar (2012). Stakeholder's involvement is the moderating variable in our study. We adapt the components from Huang et al., (2015) in order to generate the scale for stakeholder's involvement. We also include different control variables (Inflation, unemployment, and climate change) in our study by following the previous work by Abdullah et al., (2017).

\section{Results and Discussion}

We report the descriptive statistics and correlation analysis in table 1 . The results of regression

Table 1. Descriptive Statistics and Correlation

\begin{tabular}{|c|c|c|c|c|c|c|c|c|c|c|c|c|}
\hline No & Variable & $\mathbf{M}$ & SD & 1 & 2 & 3 & 4 & 5 & 6 & 7 & 8 & 9 \\
\hline 1 & Inflation & 3.77 & 0.70 & 1 & & & & & & & & \\
\hline 2 & Poverty & 3.98 & 0.42 & $.168^{*}$ & 1 & & & & & & & \\
\hline 3 & $\begin{array}{l}\text { Climate } \\
\text { Change }\end{array}$ & 3.78 & 0.65 & .012 & -.040 & 1 & & & & & & \\
\hline 4 & Unemployment & 3.88 & 0.94 & $.169 *$ & $.180 * *$ & 0.053 & 1 & & & & & \\
\hline 5 & $\begin{array}{l}\text { Agriculture } \\
\text { Initiative }\end{array}$ & 4.10 & 0.62 & 0.030 & $.210 * *$ & $0.139 *$ & $.192 * *$ & 1 & & & & \\
\hline 6 & $\begin{array}{l}\text { Economic } \\
\text { Initiative }\end{array}$ & 4.23 & 1.05 & $.250 * *$ & $.129 *$ & $0.066^{*}$ & 0.056 & 0.115 & 1 & & & \\
\hline 7 & $\begin{array}{l}\text { Infrastructure } \\
\text { Initiative }\end{array}$ & 3.89 & 0.95 & $0.37 * *$ & $.052 *$ & 0.038 & 0.027 & 0.055 & .075 & 1 & & \\
\hline 8 & $\begin{array}{l}\text { Stakeholder } \\
\text { Involvement }\end{array}$ & 3.99 & 1.56 & $0.49 *$ & $0.099 * *$ & $0.044^{*}$ & 0.003 & $0.261 *$ & $0.11 * *$ & $0.06^{*}$ & 1 & \\
\hline 9 & Food Security & 3.90 & 1.10 & $0.56 * *$ & 0.21 & $0.43 * *$ & $0.533^{*}$ & $0.21 *$ & 0.081 & 0.009 & $0.32 * *$ & 1 \\
\hline
\end{tabular}

Note. $\mathrm{N}=143 . * \mathrm{p}<.05 ; * * \mathrm{p}<.01, \mathrm{M}$ represents Mean, SD denotes standard deviation 
Table 2. Stepwise Regression Analysis

\begin{tabular}{|c|c|c|c|c|c|c|c|c|c|c|c|c|c|c|}
\hline \multirow[t]{2}{*}{ Predictors } & \multicolumn{2}{|c|}{ Model 1} & \multicolumn{2}{|c|}{ Model 2} & \multicolumn{2}{|c|}{ Model 3} & \multicolumn{2}{|c|}{ Model 4} & \multicolumn{2}{|c|}{ Model 5} & \multicolumn{2}{|c|}{ Model 6} & \multicolumn{2}{|c|}{ Model 7} \\
\hline & Estimate & SE & Estimate & SE & Estimate & SE & Estimate & SE & Estimate & SE & & & & \\
\hline Control Variables & & & & & & & & & & & & & & \\
\hline Inflation & $-0.103 *$ & 0.052 & 0.134 & 0.126 & 0.159 & 0.123 & 0.135 & 0.127 & 0.133 & 0.120 & 0.102 & 0.020 & 0.122 & 0.120 \\
\hline Climate Change & $-0.193 * *$ & 0.073 & 0.096 & 0.081 & 0.076 & 0.072 & 0.062 & 0.075 & 0.079 & 0.071 & 0.039 & 0.171 & 0.109 & 0.022 \\
\hline Unemployment & -0.201 & 0.029 & 0.002 & 0.009 & 0.001 & 0.009 & 0.001 & 0.009 & 0.009 & 0.010 & 0.129 & 0.015 & 0.042 & 0.210 \\
\hline Independent Variables & & & & & & & & & & & & & & \\
\hline Agricultural Initiatives & & & $0.014 *$ & 0.007 & $-0.268^{* *}$ & 0.135 & & & & & & & & \\
\hline Economic Initiatives & & & & & & & $0.107^{* *}$ & 0.041 & $-0.418^{*}$ & 0.211 & & & & \\
\hline Infrastructure Initiatives & & & & & & & & & & & $0.079 *$ & $0.030 * *$ & -0.568 & 0.137 \\
\hline Moderator & & & & & & & & & & & & & & \\
\hline Stake Holder Involvement & & & & & -0.271 & 0.087 & & & $-0.461^{* *}$ & 0.121 & & & $-0.465^{*}$ & 0.232 \\
\hline Interaction Terms & & & & & & & & & & & & & & \\
\hline $\begin{array}{l}\text { Agricultural Initiatives } \mathrm{X} \\
\text { Stake Holder Involvement }\end{array}$ & & & & & $0.098 * *$ & 0.037 & & & & & & & & \\
\hline $\begin{array}{l}\text { Economic Initiatives X } \\
\text { Stake Holder Involvement } \\
\text { Infrastructure Initiatives X } \\
\text { Stake Holder Involvement }\end{array}$ & & & & & & & & & $0.314 * *$ & 0.119 & & & $0.287^{* *}$ & 0.109 \\
\hline$R^{2}$ & 0.10 & & 0.350 & & 0.542 & & 0.31 & & 0.5 & & & 94 & 0.5 & \\
\hline
\end{tabular}

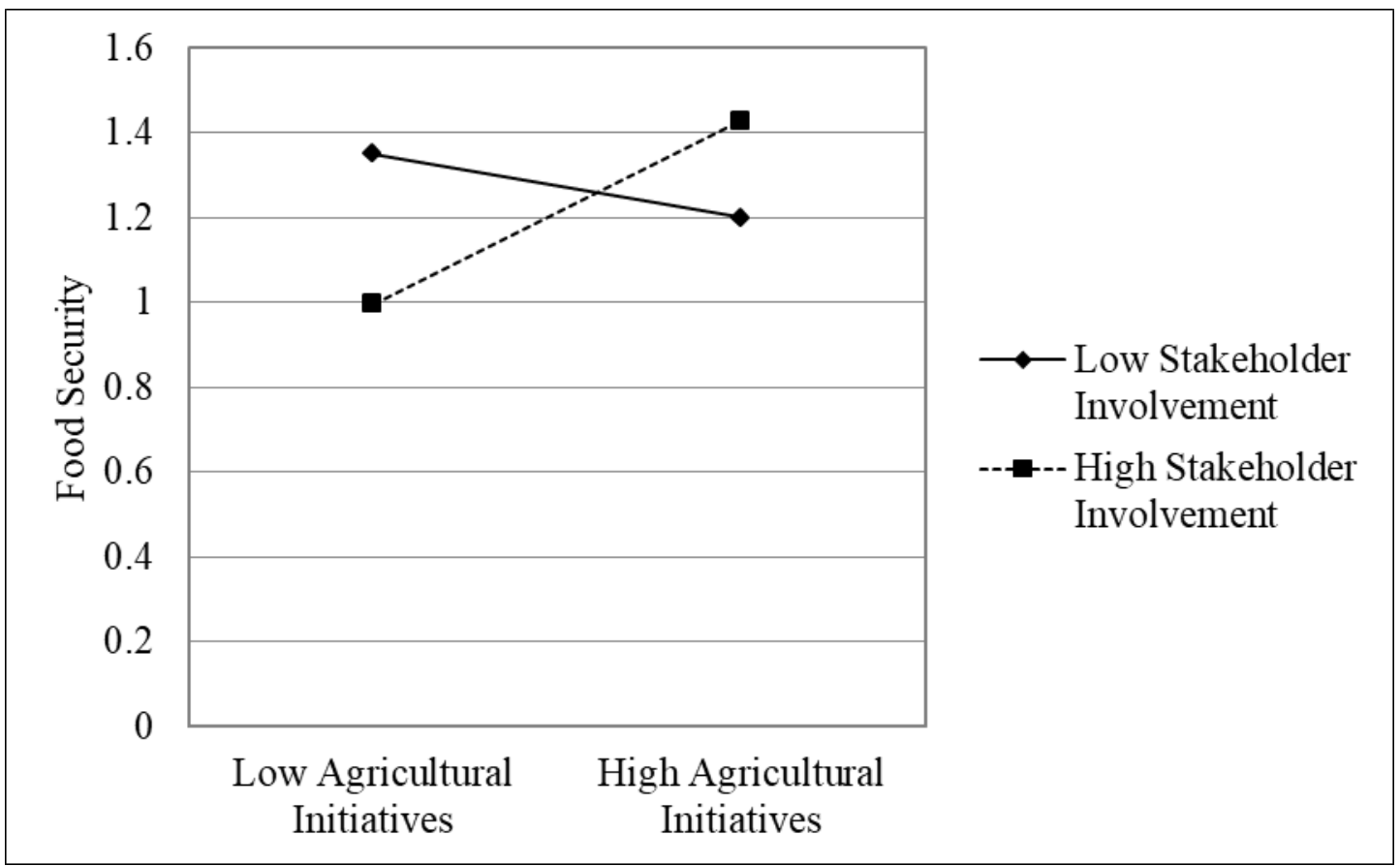

Figure 5. Agriculture Initiatives, stakeholder involvement and Food Security Source: Dawson (2014) 


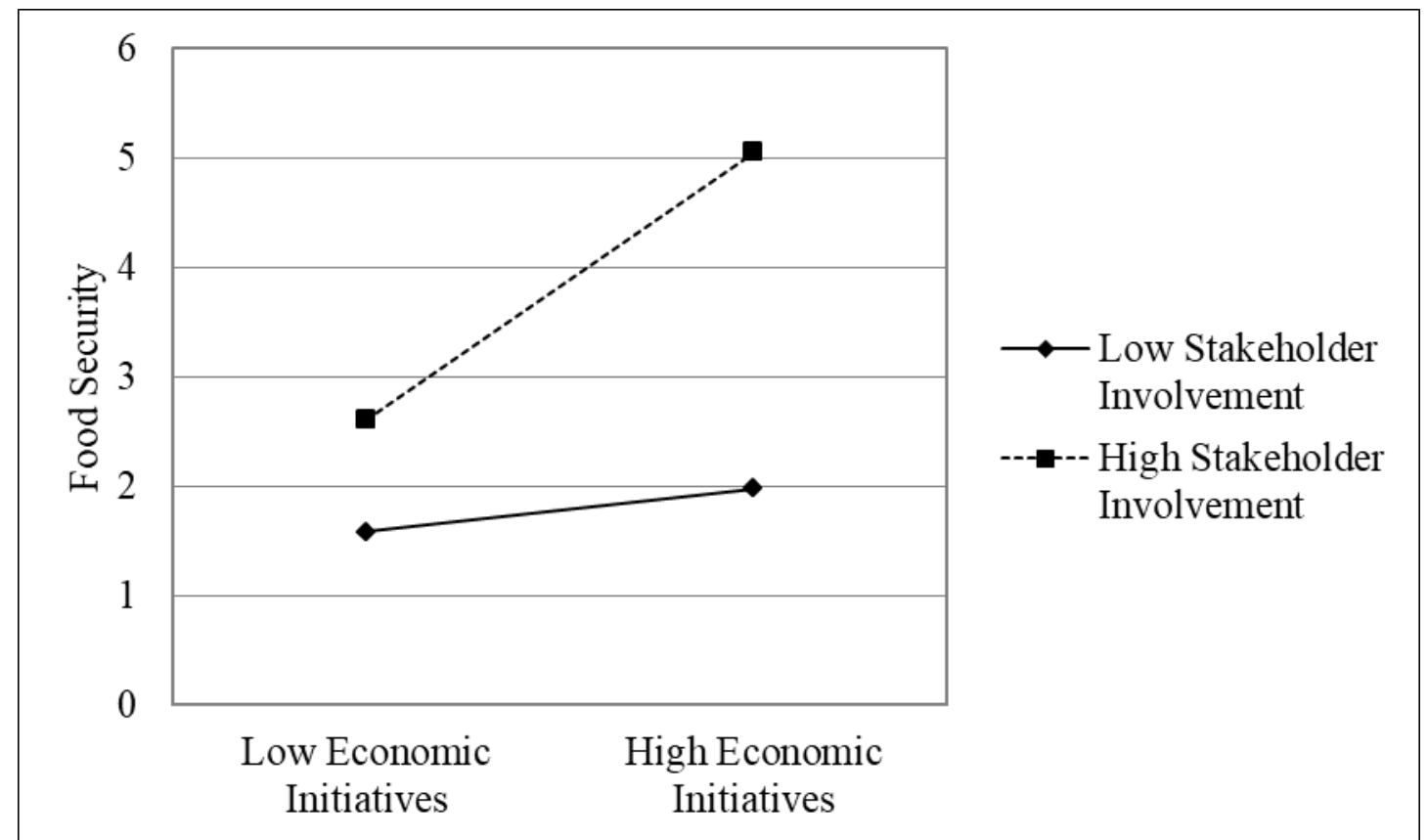

Figure 6. Economic Initiatives, stakeholder involvement and Food Security Source: Dawson (2014)

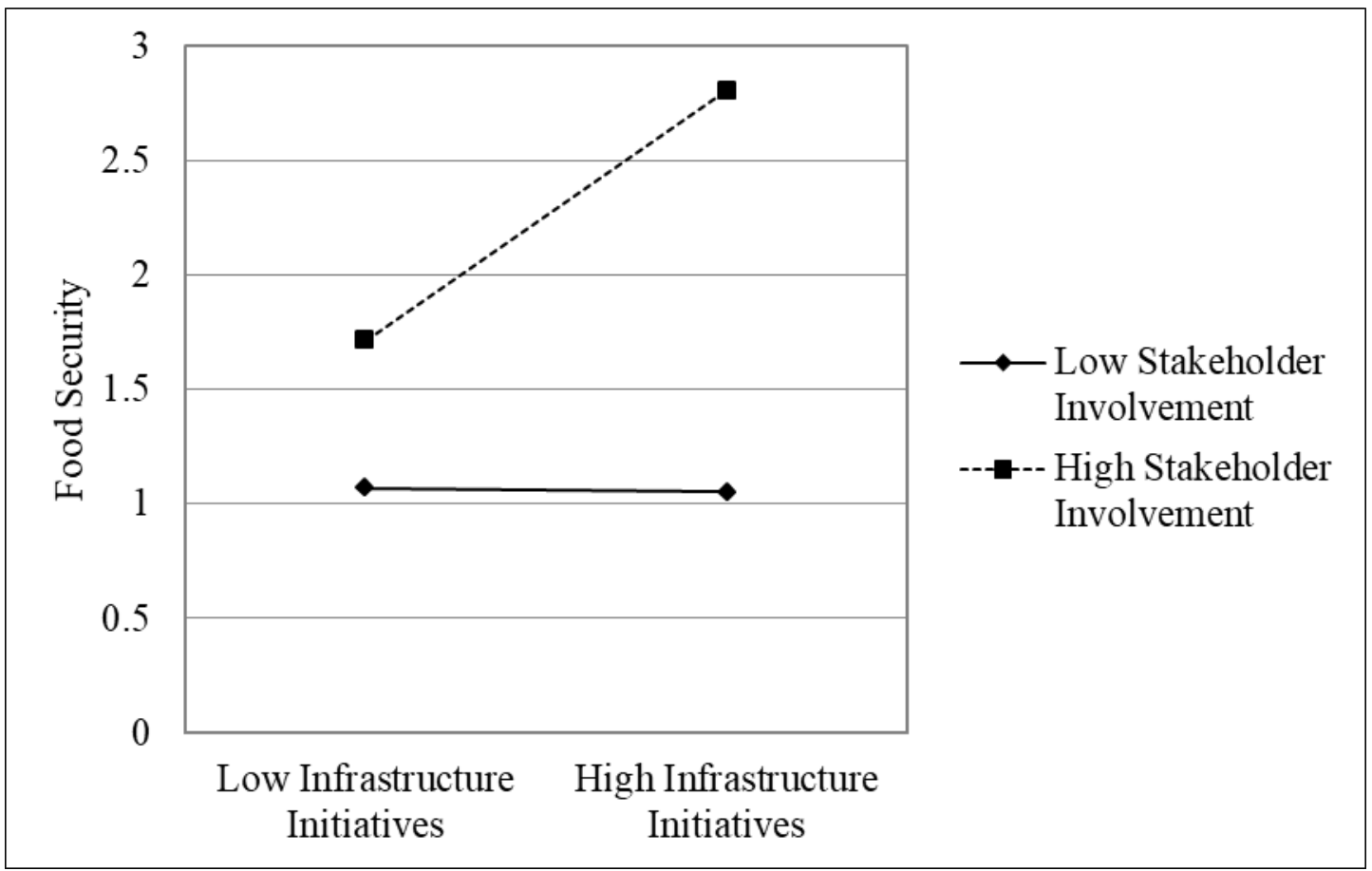

Figure 7. Infrastructure Initiatives, Stakeholder Involvement and Food Security

Source: Dawson (2014)

analysis are reported in table 2 . The results show that impact of all the independent variables on food security situation is positive and statistically significant. If we discuss one by one then we may see that coefficient of agricultural initiatives is 0.014 which is statistically 
significant at 95\% confidence level (Please see Model 2 in Table 2). The coefficient of economic initiatives is 0.107 which is statistically significant at $99 \%$ confidence level (Please see Model 4 in Table 2). Finally, we may observe that coefficient of infrastructure initiatives is 0.079 which is statistically significant at 5\% significance level (Please see Model 6 in Table 2). We may further notice that economic impact of all the initiatives is amplified in the presence of stakeholder involvement (Please see Models 3, 5 \& 7 in Table 2). Following Dawson (2014), In order to robust check the findings of our moderation analysis, we draw different interaction diagrams (Please see figures 5-7) between economic initiatives and food security, agricultural initiatives and food security, and infrastructural development initiatives and food security at low-and high levels of stakeholder involvement. To summarize it, we can say that all the hypotheses of this study are fully supported.

\section{Conclusion}

China has now become bigger country with great foreign direct investment in Pakistan in different sectors like energy, agriculture, infrastructure, ports and telecommunication ("China is Investing", August 28, 2017). The development of CPEC makes Pakistan to be a first economic hub among the South Asian countries (Nilofar et al., 2014). CPEC may be considered as a "Game Changer" for Pakistan for its ultimate influence on the development of most significant socio-economic aspects like employment, and food security etc. Growth in agricultural productivity plays a significant role to stimulate the process of economic growth in most of the countries (Johnston and Mellor 1961; Timmer, 2005). In Pakistan, agriculture sector accounts for 19.53\% of Pakistan's GDP (Pakistan Economic Survey, 2016-17) which makes it highly dependent on agricultural production while the agriculture sector is passing through structural transformation (Dawn, 2017) that not only demands for the farms modernization but to develop investment strategies with new approaches as well. Having undernourished infrastructure, most of food in Pakistan is wasted during the supply chain process. Hence, such problem could be resolved through the construction of a planned infrastructure that may ease the communication/transportation from town/villages/cities to marketplaces (Imran, 2017). Fortunately, CPEC could provide a better chance to boost up the economic activities along with developing high standards of transport infrastructure, and agricultural productivity by attributing significant growth to food regions (Dobermann et al., 2013).

The focus of current study was to investigate the impact of CPEC on food security situation of Pakistan only. In future, studies could be conducted to investigate this relationship in those other countries coming under the realm of OBOR. In addition, it is expected to have some different findings if survey will be conducted while considering experts from specific areas and departments, or taking into account the views of the local population.

\section{References}

Abdullah, A., Zhou, D., Shah, T., Ali, S., Din, I. U., \& Ilyas, A. (2017). Factors affecting household food security in rural northern hinterland of Pakistan. Journal of the Saudi Society of Agricultural Sciences. 
Ali, L., Mi, J., Shah, M., Shah, S. J., Khan, S., Ullah, R., \& Bibi, K. (2018). Local residents' attitude towards road and transport infrastructure (a case of China Pakistan economic corridor).Journal of Chinese Economic and Foreign Trade Studies, 11(1), 104-120. https://doi.org/10.1108/JCEFTS-08-2017-0024

Alkire, S. (2002). Dimensions of human development. World development, 30(2), 181-205. https://doi.org/10.1016/S0305-750X(01)00109-7

Allard, S. W., Wathen, M. V., Shaefer, H. L., \& Danziger, S. K. (2017). Neighborhood Food Infrastructure and Food Security in Metropolitan Detroit. Journal of Consumer Affairs. https://doi.org/10.1111/joca.12153

Asghar, Z., \& Muhammad, A. (2013). Socio -Economic Determinants of Household Food Insecurity in Pakistan. Munich: MPRA. Retrived From <https://mpra.ub.uni muenchen.de/21510/>

Breisinger, C., Ecker, O., Al-Riffai, P., \& Yu, B. (2012). Beyond the Arab Awakening: Policies and Investments for Poverty Reduction and Food Security. Food policy report (IFPRI), February.

Brunner, H. (2013), What is Economic Corridor Development and What Can ItAchieve in Asia's Subregions?, ADB Working Paper Series on Regional Economic Integration, 117, Asian Development Bank.

Chaudhri, T. (2017). The China-Pakistan Economic Corridor (CPEC) (Doctoral dissertation, The Ohio State University).

Choi, C. (2006) Does foreign direct investment affect domestic income inequality?, Applied Economics Letters, 13(12), 811-814. https://doi.org/10.1080/13504850500400637

Chohan, U. W. (2017). What Is One Belt One Road? A Surplus Recycling Mechanism Approach.

Dawson, J. F. (2014). Moderation in management research: What, why, when, and how. Journal of Business and Psychology, 29(1), 1-19. https://doi.org/10.1007/s10869-013-9308-7

Djokoto, J. (2012). Effects of Foreign Direct Investment Inflows into Agriculture on Food Security in Ghana. Journal of Economics and Sustainable Development, 2.

Dobermann, A., Nelson, R., Beever, D., Bergvinson, D., Crowley, E., Denning, G., \& Lynam, J. (2013). Solutions for sustainable agriculture and food systems. Sustainable Development Solutions Network, New York, NY, USA.

FAO, WFP, \& IFAD. (2012). The state of food insecurity in the world. Rome: Food And Agriculture Organization Of The United Nations.

FAO. (2015). AQUASTAT: Pakistan. Food and Agriculture Organization, Retrieved fromhttp://www.fao.org/nr/water/aquastat/countries regions/PAK/index.stm

FAO, I., \& UNICEF. (2018). WFP and WHO (2017). The State of Food Security and Nutrition 
in the World 2017: Building Resilience for Peace and Food Security.

Faruqee, R. (Ed.). (1999). Strategic reforms for agricultural growth in Pakistan. World Bank Publications. https://doi.org/10.1596/0-8213-4336-X

Fogel, R. W. (1991). The Conquest of High Mortality and Hunger in Europe and America: Timing and Mechanisms. In Patrice

Higonnet, D., Landes, S., \& Henry, R. eds., Favorites of Fortune: Technology, Growth, and Economic Development since the Industrial Revolution (Cambridge, MA: Harvard University Press), pp. 35-71.

Gandhi, V. P., \& Zhou, Z. (2014). Food demand and the food security challenge with rapid economic growth in the emerging economies of India and China. Food Research International, 63, 108-124 https://doi.org/10.1016/j.foodres.2014.03.015

Gerlach, A. C., \& Liu, P. (2010). Resource-seeking Foreign Direct Investment in African Agriculture A review of country case studies. FAO Commodity and Trade Policy Research Working Paper No. 31.

Governance. Development and Strengthening of Infrastructure facilities for production. Distribution and Marketing of quality seeds in Khyber Pakhtunkhwa. (2017). KPCPEC. Retrieved from http://www.cpec.kp.gov.pk/news/development-and-strengtheninginfrastructure-facilities-production-distribution-and-marketing

Hair, J. F., Black, W. C., Babin, B. J., \& Anderson, R. E. (2010). Multivariate Data Analysis, $7^{\text {th }}$ Ed., Pearson Prentice Hall, Upper Saddle River, NJ.

Hallam, D. (2011). International investment in developing country agriculture-issues and challenges. Food Security, 3(1), 91-98. https://doi.org/10.1007/s12571-010-0104-1

How will CPEC boost Pakistan economy?". (2015). Deloitte. Retrieved from $<$ https://www2.deloitte.com/content/dam/Deloitte/pk/Documents/risk/pak-china-ec ocorridor-deloittepk-noexp.pdf>

Huang, Y., Fischer, T. B., \& Xu, H. (2017). The stakeholder analysis for SEA of Chinese foreign direct investment: the case of 'One Belt, One Road' initiative in Pakistan. Impact Assessment and Project Appraisal, 35(2), 158-171.

Irshad, M. S. (2015). One Belt and One Road: Dose China-Pakistan Economic Corridor Benefit for Pakistan's Economy?

Ishida, M., \&Isono, I. (2012). Old, New and Potential Economic Corridors in the Mekong Region. Emerging Corridors in the Mekong Region, BRC Research Report, (8).

Jenkins, J. C., \& Scanlan, S. (2001). Food Security in Less Developed Countries, 1970-1990. American Sociological Review, 66(5), 718-44. https://doi.org/10.2307/3088955

Johnson, G., Scholes, K., \& Whittington, R. (2008). Exploring corporate strategy: text and cases. Harlow: Pearson Education. 
Johnston, B. F., \& Mellor, J. W. (1961). The role of agriculture in economic development. The American Economic Review, 51(4), 566-593.

Kirby, M., Mainuddin, M., Khaliq, T., \& Cheema, M. J. M. (2017). Agricultural production, water use and food availability in Pakistan: Historical trends, and projections to 2050.Agricultural Water $\quad$ Management, $\quad$ 179, https://doi.org/10.1016/j.agwat.2016.06.001

Kuznets., S. (1966). Modern Economic Growth.New Haven, CT: Yale UniversityPress.

Marrian, B. (2001). Towards a general theory of corridor development in South Africa. SATC 2001 .

Matthews, A. (2010). Economic partnership agreements and food security. Institute for International Integration Studies Discussion Paper, (319).

Mellor, J. W., Khan, M. H., \& Qureshi, S. K. (1991). Agricultural Links to Nonagricultural Growth: Urbanization, Employment, Poverty [with Comments]. The Pakistan Development Review, 30(4), 439-456. https://doi.org/10.30541/v30i4Ipp.439-456

Mozumdar, L. (2012). Agricultural productivity and food security in the developing world. Bangladesh Journal of Agricultural Economics. XXXV, 1, 53-69.

Muthén, L. K., \& Muthén, B. O. (2006). Chi-square difference testing using the SatorraBentler scaled chi-square. Retrieved January, 1, 2007.

National Food Security Policy (Septemper, 2017). Government of Pakistan Ministry of National Food Security and Research Islamabad. Available at (Accessed on January 5, 2018)

Nilofar, M., Jiang, W. S., \& Ishtiaque, M. (2014). The growing economic ties between Pakistan and china and its impact on the economy of Pakistan. IMPACT: International Journal of Research in Humanities, Arts and Literature, 2(12), 49-54.

Overholt, W. H. (2016). China and the evolution of the world economy. China Economic Review, 40, 267-271. https://doi.org/10.1016/j.chieco.2016.07.005

Paul, H., \& Steinbrecher, R. (2013). African agricultural growth corridors and the new alliance for food security and nutrition. Who benefits, who loses.

Pakistan Economic Survey. (2015). Government of Pakistan. Ministry of Finance Retrieved From http://www.finance.gov.pk/survey_1516.html

Qureshi, M. E., Dixon, J., \& Wood, M. (2015). Public policies for improving food and nutrition security at different scales. Food Security, 7(2), 393-403. https://doi.org/10.1007/s12571-015-0443-z

Railway track project planned from Karachi to Peshawar. (2015, November 14). Pakistan Tribune. Retrieved from http://paktribune.com/news/Railway-track-project-planned from-Karachi-to-Peshawar-275016.html

Safitri, H. (2012). Economic Corridor Policy, Land Concentration and 'Social 


\section{Mll Macrothink}

Journal of Public Administration and Governance ISSN 2161-7104 2019, Vol. 9, No. 1

Exclusion'Java's Economic Corridor Policy Implementation, Indonesia. International Institute of Social Studies, The Hague, Netherlands, 2012.

Satorra, A., \& Bentler, P. M. (2001). A scaled difference chisquare test statistic for moment structure analysis. Psychometrika, 66, 507-514. https://doi.org/10.1007/BF02296192

Sazanami, Y. (1995). The East Asian Miracle: Economic Growth and Public Policy. A World Bank Policy Research Report. London: Oxford University Press, 1993. xvii, 289 pp. The Journal of Asian Studies, 54(1), 184-185. https://doi.org/10.2307/2058969

SDPI. (2009). Food Insecurity in Pakistan. Sustainable Development Policy Institute, Islamabad, World Food Program Pakistan, Swiss Agency for Development and Corporation.

Timmer, C. P. (2005). Food security and economic growth: an Asian perspective. Asian Pacific Economic Literature, 19(1), 1-17. https://doi.org/10.1111/j.1467-8411.2005.00155.x

Timmer, C. P. (2010). Reflections on food crises past. Food Policy, Elsevier, 35(1), 1-11, February. https://doi.org/10.1016/j.foodpol.2009.09.002

Transportation Infrastructure [Editorial]. (2017). Youlin Magzine. Retrieved from http://www.cpecinfo.com/road-infrastructure

Ul Haq, M. (1995). Reflections on human development. oxford university Press.

Von Grebmer, K., Bernstein, J., Hossain, N., Brown, T., Prasai, N., Yohannes, Y., \& Foley, C. (2017). 2017 global hunger index: The inequalities of hunger. Intl Food Policy Res Inst.

Voss, R. (2016). Foreign Direct Investment (FDI): A means to address food insecurity? A Nexus Analysis.

Wolf, S. O. (2016). The China-Pakistan Economic Corridor: An Assessment of its Feasibility and Impact on Regional Cooperation.

Weng, L., Boedhihartono, A. K., Dirks, P. H., Dixon, J., Lubis, M. I., \& Sayer, J. A. (2013). Mineral industries, growth corridors and agricultural development in Africa. Global Food Security, 2(3), 195-202. https://doi.org/10.1016/j.gfs.2013.07.003

Zhou, D., Shah, T., Ali, S., Ahmad, W., Din, I. U., \& Ilyas, A. (2017). Factors affecting household food security in rural northern hinterland of Pakistan. Journal of the Saudi Society of Agricultural Sciences.

Karachi to Lahore motorway project approved. (2014, July 4). The Dawn Media Group. <https://www.dawn.com/news/1116948/karachi-to-lahore-motorway-project approved>

Kugelman, M. (2015, July 9). Pakistan's Other National Struggle: Its Energy Crisis. The Wall Street Journal. <https://blogs.wsj.com/washwire/2015/07/09/pakistans other-national-struggle-its- energy-crisis/>

Rashid, A. (2015, December 7). A Miracle on the Indus River? The China-Pakistan Economic Corridor has the potential to transform Pakistan's economy. The Diplomat. Retrieved from http://thediplomat.com/2015/12/a-miracle-on-the-indus-river/ 
Ahmed, A. (January 8, 2017). Agriculture growth rising, but may not sustain. Retrieved from<https://www.dawn.com/news/1307023> (Accessed on January 7, 2018)

Mohsen, G. (2017, 4). Food Security and Regional Development: Potential of China Pakistan Economic Corridor. IAPS Dialogue: The online magazine of the Institute of Asia \& Pacific Studies.<https://iapsdialogue.org/2017/04/19/food-security and regional development-potential-of-china-pakistan-economic-corridor/>

UNCTAD. (2017, April). The Role of Science, Technology And Innovation In Ensuring Food Security By 2030. Paper presented at United Nations Conference on Trade and Development, New York and Geneva. Retrieved from http://www.finance.gov.pk/survey_1516.html

CPEC investment to focus on Agriculture. (2017, May17). Asia Unhedged. Retrieved from http://www.atimes.com/article/cpec-investment-focus-agriculture/

Imran, M. (2017, June 17). Oxfam joins hands with Indus Consortium to raise awareness about food wastage and fighting hunger. The News. Retrieved from https://www.thenews.com.pk/print/211060-40-of-food-wasted-globally-is-in-Paki stan

Hussain, K. (2017, June 21). Exclusive: CPEC master plan revealed. Dawn News. Retrieved from https://www.dawn.com/news/1333101

Global Hunger Index, Country Case Studies (October 16, 2017). Pakistan: Fighting Drought and Inequality to Ensure Food Security.

\section{Copyright Disclaimer}

Copyright for this article is retained by the author(s), with first publication rights granted to the journal.

This is an open-access article distributed under the terms and conditions of the Creative Commons Attribution license (http://creativecommons.org/licenses/by/4.0/). 